\title{
The Agricultural Extension Services to Stock Farmers through Utilizing The Probio_Fm in Improving The Productivity of Beef Cattle in Central Bangka, Indonesia
}

\author{
Rufti Puji Astuti ${ }^{1}$, Fahmida Manin ${ }^{2}$, Adriani $^{3}$, Novyandra Ilham Bahtera ${ }^{4}$ and Cut Rabiatul \\ Adawiyah $^{5}$ \\ \{novyandra.ib@gmail.com\} \\ ${ }^{I}$ Department of Agribusiness, University of Bangka Belitung, Bangka, Indonesia. ${ }^{2}$ Department of \\ Animal Science, University of Jambi, Jambi, Indonesia. \\ ${ }^{3}$ Department of Veterinary Clinical Studies, University of Jambi, Jambi, Indonesia. \\ ${ }^{4}$ Department of Agribusiness, University of Bangka Belitung, Bangka, Indonesia. \\ ${ }^{5}$ Center of Socio-Economic and Agriculture Policy, Ministry of Agriculture, Bogor, Indonesia.
}

\begin{abstract}
The income of stock farmers relies on the beef cattle farming. However, the practice is still far from the ideal. The extension is crucial to be implemented to tackle the issue. The aim of the extension for the farmer group in Bangka Tengah Regency is to introduce the product called as probio_FM as well as to educate them on its benefit and how to use it properly. Three steps were implemented on the extension: transferring knowledge, assisting the application of probio_FM in making animal feed and evaluating the result of application of animal feed. The method of the extension were delivering lecture, having discussion and showing how to use it. The result showed that most of stock farmers had a positive attitude towards the provided extension. Furthermore, the study found that the majority of the stock farmers received a well-explained direction of using the probio_FM. The willingness to use the probio_FM considered as high. The study also found that the feeding implementation positively impacted increasing appetite, gaining weight, reducing urine and feces odors, and extending the expiration of raw material of animal feed. It concludes that the introduction of the probio FM to the stock farmers is able to raise the awareness and improve skills of stock farmers in utilizing local livestock feed and producing the fermented feed. Its use is able to improve the level of feed digestibility, livestock condition and cage environment, feeding management and reducing feed costs.
\end{abstract}

Keywords: Central Bangka, beef cattle, farmer group

\section{Introduction}

The beef cattle production has become one of the main industries for stock farmers in Padang Baru Village, Central Bangka, Indonesia. It is considered as the main livelihood for most of the people. It is due the economic potential, their ability and hobby in raising the cattle. Furthermore, the support of government contributes in encouraging stock farmers being serious in the activity of raising the cattle. The program of government in supporting the stock farmers by providing the brood cow is implemented with shift system. To be effective, 
government provides extension and forms the farmer group. Tunas Hijau farmer group is one of the established farmer groups made by department of agriculture and livestock of Central Bangka Regency in Padang Baru Village. 20 members of farmer group are leaded by $\mathrm{Mr}$ Rusli. The high cost of feeding is one of the obstacles faced by stock farmers in beef cattle production; as a result, the stock farmers gain low income. $80 \%$ of cost are only spent in the food procurement for cattle.

There are two types of required feeding in the beef cattle production: green and concentrate feeds. In Padang Baru Village, the stock farmers have provided both of them to their cattle. However, the use of concentrate feeds has not met the expected productivity of beef cattle production. On the other hand, the use of concentrate feeds causes the high production cost as stock farmers should add the expenditure to purchase the materials of concentrate feeds. Hence, it requires to find the answer on how to examine the effective use of concentrate feeds so that it achieves the increasing productivity in beef cattle production.

The concentrate feeds procurement can be obtained from agricultural, plantation and other industries waste materials [1]. Those are utilized by the Tunas Hijau farmer group. Rice bran, palm kernel oil, and sago pulp are the examples of feed materials derived from agricultural, plantation and other industries waste materials. In Bangka Belitung Archipelago Province, the availability of mentioned feed materials are still adequate and potentially sustainable. In here, the price of mentioned feed materials is considered as cheaper than in the other provinces i.e. in Jambi Province, Besides, the stock farmers has the access to obtain those feed materials. The stock farmers can purchase the mentioned feed materials as they want and need without any limitation of number and time. It should be utilized optimally so that the welfare of stock farmers can be achieved.

The technology plays an important role in determining the success of the stock farmers in the beef cattle production, including the food processing of probiotic - based. The use of concentrate feeds is applied directly to the cattle without any processing. It makes the ineffective result and the high production cost of the beef cattle production. Thus, the technology should contribute in using the concentrate feeds so that it can increase the beef cattle productivity, reduce the production cost and maximize the profit.

Currently, one of the most used technology of concentrate feeds processing is fermented feeds processing with the help of probiotic [2][3]. Probio_FM is a liquid probiotic consisted of some lactic acid bacteria derived from microbial isolation of digestive system of Kerinci duck [4-6].

The use of Probio_FM has been tested for poultry farming and ruminants. Its use on poultry farming has been applied in regency and some provinces in Indonesia such as Kerawang Regency, Jambi Province, Banten Province, West Java Province, and South Kalimantan Province. Its use has tremendous benefits i.e. reducing the amount of pathogenic bacteria of poultry digestive system, improving animal health, reducing environmental pollution derived from ammonia-like odor, as well as improving the productivity of duck and cattle [4][5][6-12]. Hence, it is crucial to disseminate the benefit use of Probio_FM to Tunas Hijau farmer group in Padang Baru Village, Central Bangka, Bangka Belitung Archipelago Province, Indonesia.

Some of the problems faced by Tunas Hijau farmer group are as follows:

1. The implemented feeding management is considered as simple such as feeding with only forage which reduces the cattle productivity.

2. In the feeding management, some of the stock farmers have combined low quality of raw materials for the forage and concentrate feeds so that it has no significant impact towards the productivity of cattle. 
3. The understanding of know-how in increasing the feed quality is low.

4. The source of feed materials derived from agricultural waste is abundant, accessible and inexpensive while stock farmers have low level of knowledge on how to utilize it.

5. To improve the feed quality, few stock farmers understand how to utilize the agricultural waste for feed materials using EM4 while the price of EM4 is considered as expensive which leads to the high cost of feed.

6. The productivity of cattle is low and unable to maximize the profit.

7. Stock farmers require the extension on how to utilize Probio FM as material of fermented feed and made by stock farmers taken from the available local materials in Bangka Belitung Archipelago Province.

8. The training is needed by stock farmers on how to utilize and to know the process of making the fermented feed in Probio_FM-based.

It requires an effective solution to tackle the problems faced by stock farmers. The solutions are as follows:

a. The extension will be conducted on the introduction to Probio_FM and its benefits as fermented organic materials.

b. The extension will be provided to stock farmers about step-by-step instruction of using probio_FM so that it can improve the productivity of cattle.

c. The specimen product of Probio_FM will be promoted about its composition to enhance the understanding of stock farmers towards the use of Probio_FM so that they can produce on their own.

d. The lesson materials and demo of how to use Probio_FM in composing the ration of concentrate feeds will be provided in the field.

e. There will be evaluation through the testimony of stock farmers on the use of fermented bran.

\section{Methods}

\subsection{Location and participant}

The community service was conducted in Padang Baru Village, Central Bangka Regency, Bangka Belitung Archipelago Province, Indonesia. There were 20 members of Tunas Hijau farmer group and 10 representative stock farmers of their own farmer group involved with the empowerment program.

\subsection{Materials and equipment}

Probio-FM, F3, bran, tofu pulp and water were used as the materials in this program while pail, basin, plastic and strap were used as the equipment. 


\subsection{The activity procedures}

In general, the business competitiveness in the agricultural sector can be improved by the utilization of agricultural waste as well as local-based and environment-friendly materials. This can lead to the productivity growth as the determinant factor of business competitiveness to be long-term and heritable. It emphasizes on profit maximization of beef cattle farming. The objective of community service is to introduce the Probio_FM and its benefits as well as the know-how of the application which are as follows:

a. dissemination information of the Probio_FM by showing the real product, explaining the composition and the product storage methods;

b. extension about its benefits for agricultural, fisheries and livestock sector;

c. extension about how to use Probio_FM in composing the ration of concentrate feeds;

d. demo of how to use Probio_FM in composing the ration of concentrate feeds; and

e. the extension on assisting the application of probio_FM in making animal feed.

\section{Result and Discussion}

In Tunas Hijau farmer group, some of the stock farmers put the beef cattle farming as their both main and side job. It was managed collectively under agriculture department of Central Bangka Residence. Tunas Hijau farmer group consisted of 20 stock farmers leaded by Mr. Rusli. In this farmer group, there were various livestock farming such as poultry and ruminant farming whereas most of the members in the farmer group worked in beef cattle farming. The beef cattle farming activity in the mentioned group farmer had run well. It showed from their work for being serious on the feeding management. The stock farmers had enough knowledge on type of feeds needed by beef cattle, green and concentrate feeds. Majority of stock farmers had applied both type of feeds while some of them did not provide the concentrate feeds regularly. However, the use of concentrate feeds applied by stock farmers faced some obstacles.

Even though the material of concentrates were available and accessible, the feed materials price was considered as high. It was due to the inability of stock farmers on covering the cost of beef cattle production. Damaged feed was another obstacle faced by stock farmers. The nature of concentrate feeds was damaged easily. It leaded to the inability of stock farmers on storing big amount of feeds. It became the difficulty faced by stock farmers in the beef cattle production. To conclude, those obstacles were the cause of the inability of stock farmers in maximizing the profit. The community services through providing extension was highly appreciated by Tunas Hijau farmer group, agriculture department of Central Bangka Regency as farmer group's trainer as well as the other stock farmers who acquired information about the program. It showed from the high number of attendance from both Tunas Hijau farmer group and the other farmer groups. The agriculture department of Central Bangka Regency supported the program by facilitating the program activities i.e. transportation and manpower.

The result illustrated that most of stock farmers had a little knowledge on the product called as Probio_FM. Nevertheless, they understood its benefits and use after receiving lesson materials on the program. Not only understood stock farmers on its benefits and use, but also they could conclude that Probio_FM had similar benefits with EM4 utilized by them regularly. It made the program interestingly conducted and eased the trainer on explaining Probio_FM. 
Basically, the use of Probio FM had similarity with EM4, as the fermented materials on the feed processing. However, both were different in terms of the nature of materials. The Probio FM's nature of materials was organic while EM4 was chemical. EM4 was regularly utilized by stock farmers on the feed processing. The EM4 price was considered as expensive. This leaded to the high cost of production. In addition, the use of EM4 in feed processing had no significant impact on the beef cattle production. After acquiring lesson materials about the use and benefits of Probio_FM, stock farmers were enthusiastically participated on the Q\&A session. The stock farmers were eagerly to utilize the Probio_FM in feed processing. This was due to the organic nature of the product, the inexpensive price of the product and the accessible product so that stock farmers were able to produce on their own.

The program followed by demonstrating the use of Probio_FM for feed processing. The demo showed the fermented bran on feed processing. The result of the demo figured that most of the stock farmers had understood on how to use Probio_FM as the fermented bran on feed processing. The stock farmers argued that the fermented bran on feed processing was simple. Moreover, they asked about the alternative application of probiotic in the feed processing beside fermented bran. The stock farmers complained about the damaged feed of sago pulp which was regularly used as the concentrate feeds. They described that the sago pulp used as feed materials was only expired in two days which then it was moldy and had bad odor and became waste. Thus, the knowledge on the use and benefits of Probio_FM would be useful on feed processing in the beef cattle production. The program also provided 10 bottles of Probio_FM for free to 10 head of stock farmers. It aimed to equip stock farmers to produce the feed of beef cattle on their own. The trial of feed processing use was actively supervised the instructor assigned by agriculture department. The task of instructor was to report and to evaluate the result of activity by filling the testimonial form to stock farmers after using the Probio_FM.

In general, the evaluation result showed positive response. The application of fermented organic materials of Probio_FM had given positively impacted on the improving feed quality, simplifying the feed management, increasing the appetite, saving the cost of feed expenditure, improving the environment of the cage and gaining weight of the beef cattle.

\section{Conclussion}

The community services on the stock farmers' empowerment program is wellimplemented. It concludes that most of the stock farmers have understood the use and benefits of Probio_FM. They also show the interest on using the Probio_FM. The program has given positive impact towards the practice of stock farmers on the feed processing. Some of the impacts on beef cattle production are increasing appetite, gaining weight, reducing urine and feces odors, and extending the expiration of raw material of animal feed. This can reduce the cost of feed processing and increase the productivity on beef cattle production.

\section{References}

[1] Simanihuruk K, Junjungan, Tarigan A. (Utilization of Oil Palm Fronds as Basal Feed for Kacang Goats on Growing Phase. In: Seminar Nasional Teknologi Peternakan dan Veteriner 2007 [Internet]. 2007. p. 417-24. Available from: http://lolitkambing.litbang.pertanian.go.id/ind/images/stories/pdf/pro07/pro07-74ks.pdf 
[2] Fuller R. Probiotics - what they are and what they do. 2003; Available from: http://www.positivehealth.com/permit/Articles/Nutrition/fuller32.htm.

[3] Thantsha MS, Mamvura CI, Booyens J. Probiotics - What They Are, Their Benefits and Challenges. 2012;(April).।

[4] Manin F, Hendalia E. Potency of Bacillus dan Lactobacillus Bacteria as Probiotik to Reduce Ammonia Pollution in Poultry House. J Peternak Indones [Internet]. 2012;14(2):360-7. Available from: file:///D:/UBB/3. Pengabdian Masyarakat/RJI/Journals/196905-ID-potensi-bakteri-bacillus-dan-lactobacill.pdf

[5] Manin F, Hendalia E, Yatno, Rahayu P. Dampak Pemberian Probiotik Probio _ FM Terhadap Status Kesehatan Ternak Itik Kerinci ( Impact of Probiotik Probio FM to Health Status of Kerinci Duck ). J ILMU TERNAK [Internet]. 2014;1( $\overline{2}): 7-11$. Available from: file:///C:/Users/Andra/Downloads/5140-8637-1-SM.pdf

[6] Yusrizal, Noverdiman, Manin F, Yatno. Pengaruh Penggunaan KombinasiProbiotik dan Prebiotik (Simbiotik) BUngkil Inti Sawit Fermentasi terhadap Penurunan Emisi Amonia Feses, Status Ksehatan dan Performans Ayam Petelur. 2012;186-96. Available from: file:///D:/UBB/3. Pengabdian Masyarakat/RJI/Journals/PIRS 2012 file-PG-TeX 32.pdf

[7] Manin F. Potensi Lactobacillus acidophilus dan Lactobacillus fermentum d ari Saluran Pencernaan Ayam Buras Asal Lahan Gambut sebagai Sumber Probiotik. J Ilm Ilmu-Ilmu Peternak [Internet]. 2010;XIII(5):221-8. Available from: https://media.neliti.com/media/publications/96656-ID-potensi-lactobacillusacidophilus-dan-la.pdf

[8] Manin F, Hendalia E, Lukman H, Farhan. Pelestarian dan Budi Daya Itik Kerinci sebagai Plasma Nutfah Provinsi Jambi Berbasis Probio_FM di Kecamatan Air Hangat Kabupaten Kerinci Provinsi Jambi. J Pengabdi- pada Masy [Internet]. 2014;33(1):30-50. Available from: file:///C:/Users/Andra/Downloads/2456-Article Text-4865-1-10-20150917.pdf

[9] Hendalia E, Manin F, Yusrizal, Nasution GM. The Application of Probiotic in Increasing Protein Efficiency in Reducing Fecal Ammonia on Broiler Chicken. Agrinak [Internet]. 2012;2(1):29-35. Available from: https://media.neliti.com/media/publications/43128-EN-aplikasi-probiotik-untukmeningkatkan-efisiensi-penggunaan-protein-dan-menurunka.pdf

[10] Hendalia E, Manin F, Asra R. Aplikasi Probio _ FM Plus melalui Air Minum pada Ayam Broiler di Politani Kupang The Application of Probio _ FM Plus through drinking water in broiler at Politani Kupang. J Ilmu-Ilmu Peternak [Internet]. 2017;20(1):33-8. Available from: file:///C:/Users/Andra/Downloads/4362-Article Text-8733-1-10-20180104.pdf

[11] Ikhwan RM, Rukmi I, Pujiyanto S. Penurunan Kadar Amonia Feses Ayam Pedaging Menggunakan Prebiotik Bungkil Inti Sawit dengan Inokulum Bakteri Lactobacillus acidophilus, Lactobacillus bulgaricus, dan Bacillus cereus. J Biol [Internet]. 2016;5(3):1-6. Available from: file://D:/UBB/3. Pengabdian Masyarakat/RJI/Journals/19497-39507-1-SM.pdf

[12] Riza H, Wizna, Rizal Y, Yusrizal. Probiotic Role for Lowering Ammonia in Poultry Feces. J Peternak Indones [Internet]. 2015;17(1):19-26. Available from: https://media.neliti.com/media/publications/196724-ID-peran-probiotik-dalammenurunkan-amonia.pdf 